\title{
SWOT analysis for orchid conservation in a forest at Mount Sanggara, West Java, Indonesia
}

\author{
INDRA FARDHANI ${ }^{1, \boldsymbol{\varphi}}$, HIROMITSU KISANUKI $^{1}$, PARIKESIT $^{2,3}$ \\ ${ }^{1}$ Graduate School of Bioresources, Mie University. Tsu, Mie Prefecture, Japan 514-0001. `email: indrafardhani@gmail.com \\ ${ }^{2}$ Department of Biology, Faculty of Mathematics and Natural Sciences, Universitas Padjadjaran. J1. Raya Bandung- Sumedang Km 21, Jatinangor, \\ Sumedang 45363, West Java, Indonesia \\ ${ }^{3}$ Postgraduate of Environmental Science and Institute of Ecology (PPSDAL), Universitas Padjadjaran. Jl. Sekeloa, Coblong, Bandung 40134, West Java, \\ Indonesia
}

Manuscript received: 9 August 2018. Revision accepted: 2 November 2018.

\begin{abstract}
Fardhani I, Kisanuki H, Parikesit. 2018. SWOT analysis for orchid conservation in a forest at Mount Sanggara, West Java, Indonesia. Asian J Ethnobiol 1: 69-74. Mount Sanggara, West Java, Indonesia, precisely in the Legok Jero area, has orchid diversity consisting of 46 epiphytic and 4 terrestrial. The diversity indexes $\left(H^{\prime}\right)$ were categorized as a medium for epiphytic and terrestrial species. The problems in Mount Sanggara are due to the conversion of forest into a coffee plantation and illegal logging, although the forest status is protected forest. Besides, orchids are also threatened by illegal collecting. Strategic management is needed to solve these problems. This study aimed to create the proper strategies to manage the forest in a sustainable way for orchid species, surrounding villages, companies, and the sustainability of the orchid community itself. This paper explores internal and external factors by SWOT analysis to formulate management strategies. Structured and unstructured interviews and questionnaires gathered data. The instruments were distributed to the company and stakeholders, farmers, and residents. Several approaches were proposed from the SWOT analysis to optimize the strengths and opportunities to overcome the weaknesses and avoid the threats. Consequently, the proposed methods can be an alternative for stakeholders to manage this forest sustainably for residents and the orchid community itself.
\end{abstract}

Keywords: Forest conservation, orchid, strategic management, sustainable habitat, SWOT

\section{INTRODUCTION}

Orchidaceae is one of the world's most prominent families of class Angiospermae (Brian and Ritterhausen 1978). Indonesia has 5,000 species out of 25,000 orchid species (Gunadi 1986; Banks 2004). There are two significant orchid species based on epiphytic and terrestrial habitats (Hew and Young 2008). Epiphytic orchids attach to the host tree trunk for living, while terrestrial orchids grow from inside the soil, humus, or litter (Hew and Young 2008).

Java Island has at least 731 species of orchids; 231 are endemic (Comber 1990). In West Java, there are 642 species of orchids (Comber 1990). The habitat loss caused by forest conversion into the plantation, farming, and settlement areas has threatened the orchid population in Java. Based on data from Forest Watch Indonesia (2014), the natural forest cover of Java Island in 2013 declined to 675,000 ha from $1,002,000$ ha in 2009. Apart from wild forests, there are limited production forests (394,314 ha) and special function forests $(1,562,733 \mathrm{ha})$. The massive forest conversion occurs in West Java Province because it is the most populated province in Indonesia with more than 46 million inhabitants (Provincial Office of West Java 2011).

Located at the border between Subang Regency and West Bandung Regency, which are included in North Bandung Area (Kawasan Bandung Utara) mountain, several forests are still in good condition. Therefore, the diversity of orchids in this area was also high, as Agustina et al. (2008) reported, identifying 41 species. Based on a previous report (Fardhani et al. 2015), Mount Sanggara, specifically in the Legok Jero area, had orchid diversity consisting of 46 epiphytic and 4 terrestrial in a 0.17 ha study area. Similar research shows the importance of studying orchid diversity in a specific place attempting to conserve (Puspitaningtyas 2007; Tsifis et al. 2007; Yahman 2009; Yulia and Budiharta 2010; Aisah and Istikomah 2014).

The problems to which Mount Sanggara has been exposed are forest conversion into coffee plantations and illegal logging, even though the forest status is protected forest managed by a government-owned company. Besides, orchids and several plants, such as ferns, wildflowers, and pitcher plants, are threatened by illegal collecting. Strategic management is needed to solve these problems. Where local people are interested in the conservation and traditional use of their lands, resources, and so forth, on condition that their fundamental human rights are respected, conflicts do not arise between the people's rights with interests and the objectives of protected areas (IUCN 2000)

SWOT (Strengths, Weaknesses, Opportunities, and Threats) analysis is an instrument for doing strategic planning which diagnoses the internal strengths and weaknesses of organizations and formulates the opportunities and threats of the environment (Rauch 2007). SWOT is a tool designed to be used in the preliminary 
stages of decision-making on the one hand and as a precursor to strategic management planning on the other (Srivastava et al., 2005). All factors influencing the operational environment are diagnosed with greater detail (Kotler 1994; Shrestha et al. 2004). This analysis has been widely used in forest environment studies (Pesonen et al. 2001; Rauch 2007; Masozera et al. 2006; Reihanian et al. 2012).

This study aimed to create the proper strategies to manage the forest in a sustainable way for orchid species, surrounding villages, companies, and the sustainability of the orchid community itself. SWOT analysis could be expected to serve as a proper tool to formulate strategic management planning for orchid conservation in the Legok Jero area.

\section{MATERIALS AND METHODS}

This study was conducted at Legok Jero Area, Mount Sanggara $\left(6^{\circ} 48^{\prime} 41.47^{\prime \prime} \mathrm{S} ; 1^{\circ} 7^{\circ} 44^{\prime} 43.80^{\prime \prime}\right.$ E) and Sunten Jaya village, West Bandung Resident, West Java Province, Indonesia (Figure 1a). Legok Jero was chosen because the abundance of orchids here is the most. The altitude in this area is around $1,700 \mathrm{~m}$ a.s.l. The study site is a secondary forest with Schima wallichii trees as the dominant species. Other components are the coffee plantation, in which coffee trees were planted under the shade of canopy trees and the crop fields (Figure 1b). The forest is protected from timber extraction under the management of a governmentowned company in forestry. Sunten Jaya village is chosen for this study because the coffee plantation belonged to a farmer group of this village. The coffee plantation is part of a program from the company called Forest Management with Local Community (Pengelolaan Hutan Bersama Masyarakat, PHBM). The company allows the nearest local community to utilize forest under shade coffee plantations to avoid forest destruction and illegal logging.

Structured and unstructured interviews and questionnaires gathered data. The data collections were performed from 10 to 12 August 2015. The sources included the staff of a state-owned company and the head of the farm group. The questionnaire was given to 340 households of Sunten Jaya village, including farm group members, during September-October 2015. The interview was held face to face with the company forest manager and head of the farm group. The farm group members and village residents were given a questionnaire too. In the questionnaires, simple Yes/No, multiple choices, and fillin-the-blank types of questions were used. The questions were kept simple to avoid misunderstanding.

Some of the questioned respondents took the questionnaire home and returned it to the data collector later. This is mainly because they were at work during the day, and it was not convenient to fill out the form directly and because they preferred to fill out the questionnaires. However, some other respondents filled the questionnaire directly in front of the collector at the farm.

Management strategies for orchids and their habitat formulated using SWOT (Strength-Weakness-OpportunityThreat) analysis. This analysis represents a systematic and comprehensive diagnosis of factors relating to a new product, technology, management, or planning (Baycheva and Wolfslehner 2015). SWOT matrix has often been used in business and extended to natural resource management to systematically assess a given decision, project, or policy directive (Schmoldt et al. 2001 in Reihanian et al. 2012). SWOT analysis doesn't determine whether a strategy is correct or incorrect. Still, this analysis helps us arrange several alternatives to overcome problems based on internal factors (strengths and weaknesses) and external factors (opportunities and threats). Applying SWOT analysis provides a good overview and makes it easy to pinpoint important problem areas (Rauch 2007).
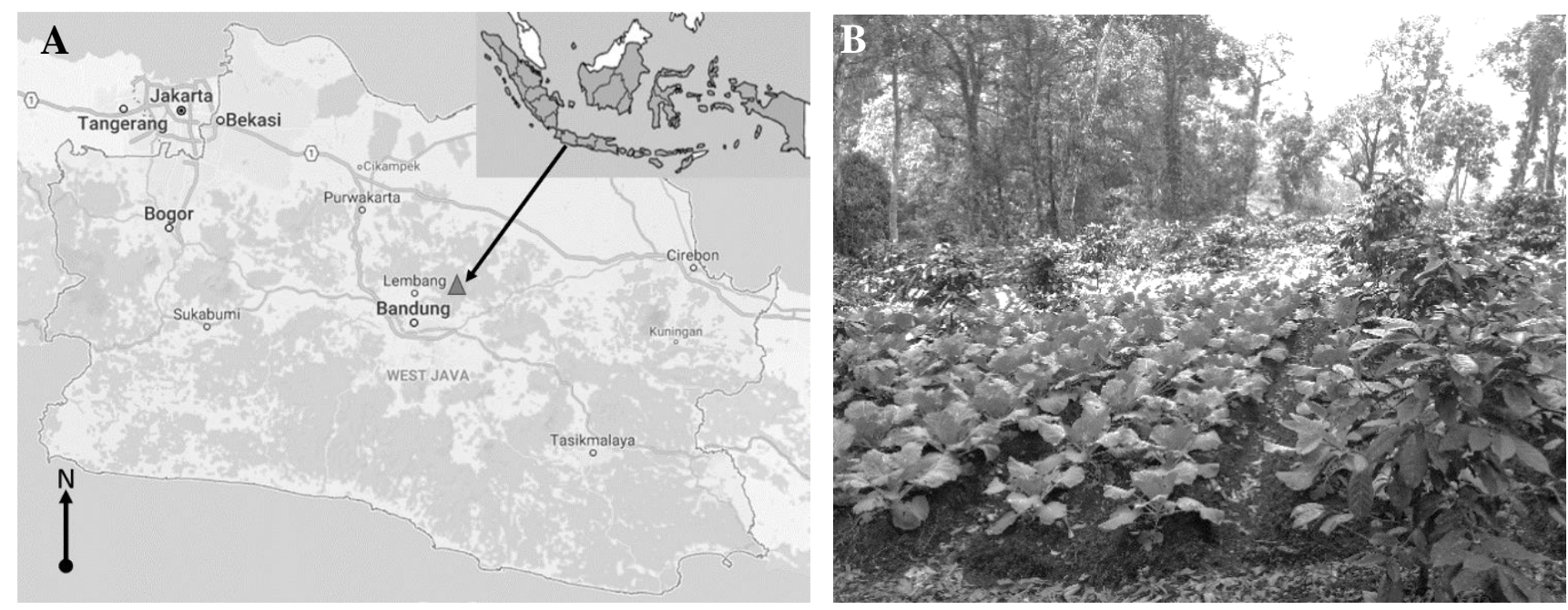

Figure 1. A. Study site map of Mount Sanggara, West Java, Indonesia, B. Crop fields made between coffee tree lines on the cleared forest floor 
Both primary and secondary data were the sources for SWOT analysis, as shown in Figure 2. The method is based on two tiers of analysis conducted separately (Reihanian et al. 2012): (i) The first step is to analyze internal factors that contain strengths and weaknesses. (ii) Second step is to analyze external factors which contain relevant opportunities and threats.

The most crucial part of SWOT is scanning the internal and external factors. The internal factors were classified as strengths (S) and Weaknesses (W). The external factors were classified as Opportunities $(\mathrm{O})$ and Threats $(\mathrm{T})$. Then matrix of Internal Factors Evaluation (IFE) and the matrix of External Factors Evaluation (EFE) were made. The factors were then weighted and calculated to get the final score.

The following section describes the process of SWOT analysis:

i. Each factor was given a coefficient between 0 and 1, standing for "not important" and "most important." The total score of the coefficient in each matrix factor should be equal to 1 in both IFE Matrix and EFE Matrix.

ii. Each factor then scored between 1 and 4 . 1 standing for poor, 2 standing for average, 3 standing for above average, 4 standing for superior (Lodato 2014).

iii. The final factor score was determined by a multiplier coefficient.

iv. After the total score of each factor was calculated, they were summed to calculate the final score for each matrix (IFE and EFE).

v. For IFE Matrix, if the value was less than 2.5 (below the average), the strengths were less than the weaknesses; if it was more than 2.5 (above the average), it meant the strength was more than the weaknesses. vi. For EFE Matrix, if the value was less than 2.5, the opportunities were less than the threats; if it was more than 2.5 , the opportunities were more than the threats (Reihanian et al., 2012; Lodato 2014).

vii. The internal and external factors then were put into the SWOT matrix to plan the management strategies (Strength-Opportunity (SO) strategies; StrengthThreat (ST) strategies; Weakness-Opportunity (WO) strategies; Weakness-Threat (WT) strategies).

viii. SWOT matrix was made by pairwise matching of each strength with each opportunity; each strength with each threat; each weakness with each opportunity; and each weakness with each threat.

ix. After matching each factor, the four groups of management strategies were then planned

\section{RESULTS AND DISCUSSION}

\section{Internal Factor Evaluation Matrix (IFE)}

The IFE Matrix is shown in Table 1. Six factors were identified as strengths of this study site. The weight allocated to these factors ranged from 0.07 to 0.12 . The rating scores ranged from 2 to 4 . The highest strength factor of this location was 'the study site status as protected forest' (weighted score $=0.48$ ). Four factors were detected as weaknesses of this study site. The weight allocated to these factors ranged from 0.09 to 0.13 . The rating scores ranged from 1 to 2 . The weakest factor considered from the study site is 'the low number of terrestrial orchid species' (weighted score $=0.26$ ). The total score of the IFE Matrix was 2.37 , less than 2.5 , implying that the strengths were less than weaknesses.

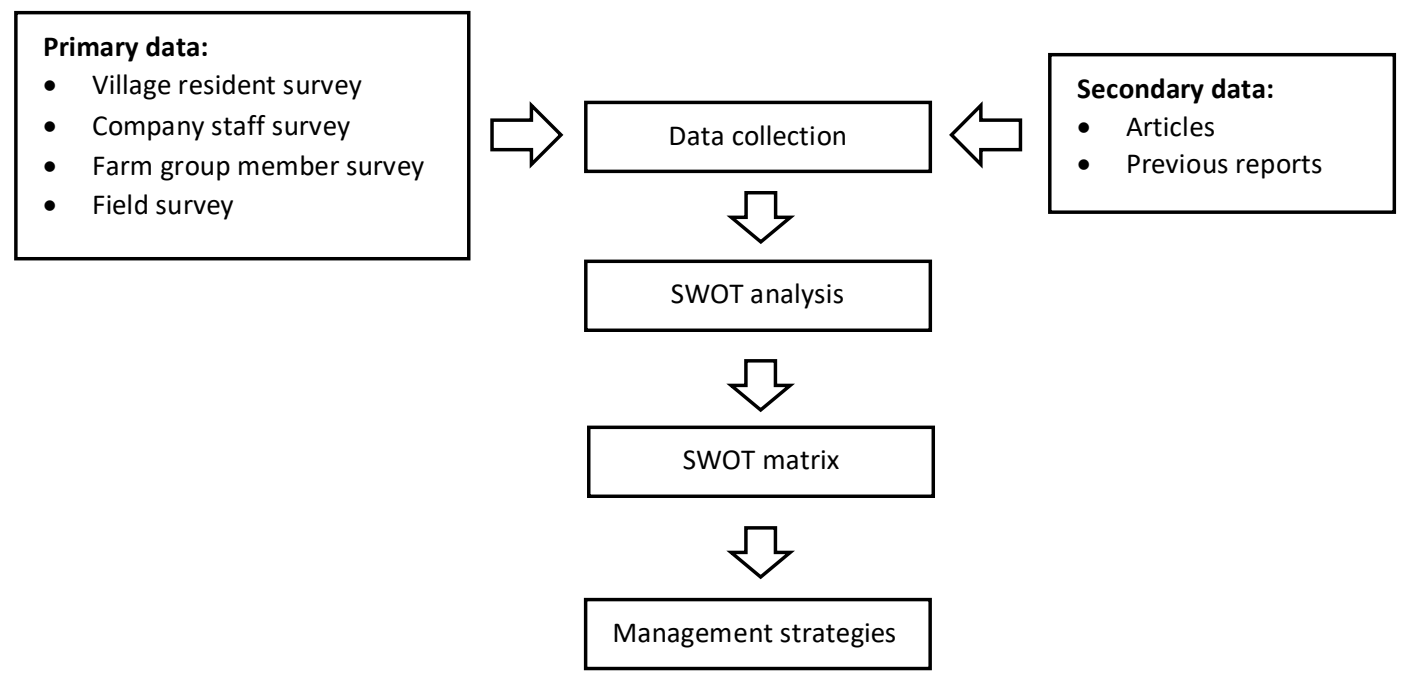

Figure 2. Research methodology outline 
Table 1. Internal Factor Evaluation Matrix

\begin{tabular}{llllll}
\hline & Internal factor & Code & Weight & Rating & $\begin{array}{l}\text { Weighted } \\
\text { score }\end{array}$ \\
\hline Strengths & The location is protected forest & S1 & 0.12 & 4 & 0.48 \\
& The location is the proper habitat for orchid growth & S2 & 0.10 & 3 & 0.30 \\
& High number of epiphytic orchid species (46 species) & S3 & 0.08 & 2 & 0.16 \\
& High abundance of epiphytic orchids. & S4 & 0.07 & 4 & 0.28 \\
& There are 7 epiphytic orchid species endemics to Java Island. & S5 & 0.10 & 4 & 0.40 \\
& Orchid species are distributed evenly. & S6 & 0.09 & 2 & 0.18 \\
Weaknesses & Low number of terrestrial orchid species (4 species) & W1 & 0.13 & 2 & 0.26 \\
& Low abundance of terrestrial orchid & W2 & 0.12 & 1 & 0.12 \\
& There is no economically valuable orchid on the study site & W3 & 0.09 & 1 & 0.09 \\
Total score & There is no law protecting orchid species on the study site & W4 0.10 & 1 & 0.10 \\
\hline
\end{tabular}

Table 2 External Factor Evaluation Matrix

\begin{tabular}{llcccc}
\hline & External factor & Code & Weight & Rating & $\begin{array}{c}\text { Weighted } \\
\text { score }\end{array}$ \\
\hline Opportunity & PHBM program reduced illegal logging in the location. & O1 & 0.15 & 4 & 0.60 \\
& Residents would be benefited from the PHBM program. & O2 & 0.13 & 4 & 0.52 \\
& Orchids were not considered as the main economic commodity for residents & O3 & 0.10 & 3 & 0.30 \\
& The residents' income was mainly low (under 100 USD/month). & O4 & 0.15 & 3 & 0.45 \\
& Residents already knew if the Mount Sanggara forest was orchid habitat & O5 & 0.07 & 2 & 0.14 \\
& Residents understood if orchid presences needed to be conserved. & O6 & 0.06 & 2 & 0.12 \\
\multirow{2}{*}{ Threat } & & & & \\
& PHBM program threatens the sustainability of terrestrial orchids. & T1 & 0.15 & 4 & 0.60 \\
& Most of the residents depended on the company forests for daily needs. & T2 & 0.10 & 3 & 0.30 \\
Total score & Residents were not familiar with legally protected orchid species. & T3 & 0.09 & 2 & 0.18 \\
& & & 1.00 & - & 3.21 \\
\hline
\end{tabular}

\section{External Factor Evaluation Matrix (EFE)}

The result of the EFE matrix is shown in Table 2. There were six factors identified as opportunities. The weights ranged from 0.06 to 0.15 . The rating scores ranged from 2 to 4 . The highest opportunity factor of this study site was PHBM program was able to reduce illegal logging in the location' (weighted score $=0.6$ ). Three factors were identified as threats. The weights were ranged from 0.09 to 0.15 . The rating scores ranged from 2 to 4 . This study site's most significant threat factor was the 'PHBM program threat the sustainability of terrestrial orchid' (weighted score $=0.6$ ). The total score of the EFE matrix was 3.21, which would imply that opportunities were more than a threat. 14 strategies were proposed for the study site to overcome the weaknesses and harness the opportunities by pairwise matching in the SWOT matrix. The proposed strategies were divided into four groups: SO strategies, WO strategies, ST strategies, and WT strategies (Table 3).

\section{Discussion}

Applying SWOT analyses provides a good overview and makes it easy to pinpoint important problem areas (Rauch 2007). SWOT analysis helped us to understand the factors (both internal and external) which would affect the forest management, resident life, orchids, and forest sustainability at the study site where the PHBM program is implemented in West Java Province. We now understood that the PHBM program had an important role in reducing illegal and destructive forest utilization. On the other hand, we also understood that the PHBM program might negatively affect the terrestrial orchid species. Forest floor clearance is the major threat for terrestrial orchid conservation besides collecting the wild orchid species (Swarts and Dixon 2009). To plant coffee trees and crops under the PHBM program at the study site, farmers cleared the forest floor, including some understory trees (Figure 1b). Not only affecting the terrestrial orchids, research by Hundera et al. (2013) in Ethiopia suggested the intensification of under-shaded coffee plantations can reduce the epiphytic orchid species richness by decreasing the density of trees and canopy cover.

None of the terrestrial and epiphytic orchids were considered as important or charismatic species at the study site by SWOT analysis (Table 1). However, we cannot let those species extinct only because they are common species. Conservation of common species is needed to ensure that they do not become uncommon or rare and thus can maintain their key ecological and functional roles in an ecosystem (Gaston 2010; Lindenmayer et al. 2011). The implementation of the PHBM program should be carefully conducted to reduce the negative effect. 
Table 3 Management strategies for orchid and habitat conservation at Mount Sanggara, West Java, Indonesia

\section{Strength-Opportunity (SO) strategies}

- $\quad$ expand the area of the PHBM program (S1, O1, O2)

- Develop eco-tourism area with coffee plantation and orchid habitat for the attractions (S1, S2, S3, S4, S5, S6, O1, O2, O5, 06)

- Promote cultivation of native orchid as a new economic commodity for residents (S2, S3, S4, S5, S6, O3, O4)

- Training program for residents about native orchid cultivation to increase their income (S2, S3, S4, S5, S6, O3, O4, O6)

Weakness-Opportunity (WO) strategies

- modify the expansion of coffee plantation to avoid the degradation of terrestrial orchid and other forest floor plants diversity (W1, W2, W4, O1, O2, O6)

- Increase the resident role in the PHBM program (W3, W4, $\mathrm{O} 1, \mathrm{O} 2, \mathrm{O} 4)$

Strength-Threat (ST) strategies

- company has to provide strict supervision related to the PHBM program (S1, S5, T1)

- $\quad$ Secure the forest to avoid illegal utilization (S1, T2)

- Education program for residents about sustainable forest utilization for their daily needs (S1, S2, T2)

- Company and stakeholders have to provide information to residents about legally protected orchids to avoid illegal collecting (S5, T3)

Weakness-Threat (WT) strategies

- termination of extension of coffee plantation area (W1, W2, T1)

- Change the method for coffee planting to be safer for understory, shrub, and ground plants. (W1, W2, T1, T2)

- Re-introduction program to increase terrestrial orchid population (W1, W2, W3, T1)

- Strict law enforcement to avoid destructive and illegal forest utilization (W1, W2, W4, T1, T2)

Note: Codes of each matrix relating to each strategy have been shown in parentheses

Based on the SWOT analysis, we proposed strategic management. All the strategies that were offered have not been implemented yet. However, these strategies can become an alternative for forest management in this area. We suggest expanding the area of the PHBM program to increase the number of residents involved so that the program would benefit them. The income of residents is primarily low and depends on the forest for fulfilling daily needs. Increasing the number of local people involved in the PHBM program will lead to income for more households. Local people may be interested in conserving biodiversity only if certain rights to use lands and forests are allocated (Harada 2003). Where local people are interested in the conservation and traditional use of their lands, resources, and so forth, on condition that their fundamental human rights are respected, conflicts do not arise between the people's rights and interests and the objectives of protected areas (IUCN 2000). Agroforestry provides a potentially valuable conservation tool to reduce land-use pressure and enhance rural livelihoods (Bhagwat et al., 2008). However, we also suggest avoiding destructive forest floor clearing that will negatively affect the population of terrestrial orchids and other native plant species.

The area of the PHBM program can also be used for ecotourism and coffee plantations. The natural orchid habitat with many epiphytic species can attract tourists to this area. Such eco-tourism can bring lots of benefits to rural zones. Ecotourism in this area may also help preserve Sundanese people's local and traditional values as tourist attractions. Rural tourism will cause the development of a village's social and economic aspects in the long term (Mahmoudi et al., 2011). With ecotourism, the resident dependency on exploitative forest resources utilization may be controlled.

This study examines the strengths, weaknesses, opportunities, and threats of the orchid community in a protected forest area in Mount Sanggara, West Bandung Regency, West Java, Indonesia. The result in some strategies has been shown. Applying SWOT analysis provided a good overview and made it easy to pinpoint critical problem areas. From the final score of SWOT analysis, the Internal Factors Evaluation score was 2.37 $(<2.5)$, indicating that the strengths were less than weaknesses. The score of External Factors Evaluation was 3.21 , indicating the opportunities were more than threats. Several strategies were proposed to optimize the strengths and the opportunities to overcome the weaknesses and avoid the threats. These results may help the forest managers analyze the PHBM program implementation problems for orchids and forest sustainability. The proposed strategies can become an alternative solution for further research on the PHBM program implementation in the study site.

\section{ACKNOWLEDGEMENTS}

Acknowledgments are conveyed to the Head of Perum Perhutani KPH Bandung Utara and BKPH Cisalak for support and permission, to the farmer group of PHBM Arjuna and all residents Sunten Jaya Village and to all those who have assisted in this research.

\section{REFERENCES}

Agustina R, Nugraha I, Muhyidin F. 2008. Inventory of orchidaceae at a mountain around Cileat waterfall in Subang Regency, West Java, National Seminar of Departement of Biology Education UPI, Universitas Pendidikan Indonesia, Bandung, 3-5 June 2008. [Indonesian]

Aisah S, Istikomah IR. 2014. Composition of terrestrial orchid and forest floor vegetation along main hiking track of Mount Andong, Magelang, Central Java. Jurnal Kaunia 10(1):65-72. [Indonesian]

Banks DP. 2004. Handy Pocket Guide to the Orchid of Indonesia. Periplus Edition (HK) Ltd, Singapore.

Baycheva-Merger T, Wolfslehner B. 2015. Evaluating the implementation of pan-european criteria and indicators for sustainable forest management - a SWOT analysis. Ecol Indicat 60: 1192-1199. DOI: 10.1016/j.ecolind.2015.09.009. 
Bhagwat SA., Willis KJ, Birks HJB, Whittaker RJ. 2008. Agroforestry: refuge for tropical biodiversity? Trends Ecol. Evol. 23(5): 261-267. DOI: 10.1016/j.tree.2008.01.005.

Brian WR .1987. Orchid as ornamental plant. Pionir Jaya, Bandung. [Indonesian]

Comber JB. 1990. Orchids of Java. Bentham-moxon Trust, The Royal Botanic Gardens, Kew.

Fardhani I, Kisanuki H, Parikesit. 2015. Diversity of orchid species in Mount Sanggarah, West Bandung, The $22^{\text {nd }}$ Tri-University International Joint Seminar and Symposium, Jiangsu University, Jiangsu, 18-23 October 2015.

Forest Watch Indonesia. 2014. Portrait of Indonesian forest condition period of 2009-2013. https://www.fwi.or.id. [Indonesian]

Gaston KJ. 2010. Valuing common species. Science. 327: 154-155. DOI $10.1126 /$ science. 1182818 .

Gunadi T. 1986. Orchid from continent to continent. Penerbit Angkasa, Bandung. [Indonesian]

Harada K. 2003. Attitudes of local people towards conservation and Gunung Halimun National Park in West Java, Indonesia. J. For. Res. 8: 271-282. DOI: 10.1007/s10310-003-0037-z.

Hew CS, Yong JWH. 2004. The Physiology of Tropical Orchids in Relation to The Industry: $2^{\text {nd }}$ ed. World Scientific Publishing, Singapore. DOI: $10.1142 / 5505$.

Hundera K, Aerts R, de Beenhouwer M, van Overtveld K, Helsen K, Muys B, Honnay O. 2013. Both forest fragmentation and coffee cultivation negatively affect epiphytic orchid diversity in Ethiopian moist evergreen Afromontane forest. Biol. Conserv. 159: 285-291. DOI: 10.1016/j.biocon.2012.10.029.

IUCN. 2000. Indigenous and traditional peoples and protected areas: principles, guidelines and case studies. (best practice protected area guidelines series no. 4). www.portals.iucn.org.

Lindenmayer DB, Wood JT, McBurney L, MacGregor C, Youngetob K, Banks SC. 2011. How to make a common species rare: a case against conservation complacency. Biol. Conserv. 144: 1663-1672. DOI: 10.1016/j.biocon.2011.02.022.

Lodato MW. 2014. A Handbook of Managing Strategic Processes Becoming Agile in A World of Changing Realities. Authorhouse, Bloomington.

Mahmoudi B, Haghsetan A, Maleki R. 2011. Investigation of obstacles and strategies of rural tourism development using SWOT matrix. J. Sustain. Dev. 4(2): 136-141. DOI: 10.5539/jsd.v4n2p136.
Masozera MK, Alavalapati JRR, Jacobson SK, Shrestha RK. 2006. Assessing the suitability of community-based management for the Nyungwe Forest Reserve, Rwanda. For. Policy. Econ. 8: 206-216. DOI: 10.1016/j.forpol.2004.08.001

Pesonen M, Kurttila M, Kangas J, Kajanus M, Heinonen P. 2001. Assessing the priorities using A'WOT among resource management strategies at the Finnish forest and park service. For. Sci. 47 (4): 534541.

Provincial Office of West Java. 2011. Population. https://www.jabarprov.go.id. [Indonesian]

Puspitaningtyas DM. 2007. Inventory of orchid and it host tree in Meru Betiri National Park - East Java. Biodiversitas 8(3): 210-214. DOI: 10.13057/biodiv/d080309. [Indonesian]

Rauch P. 2007. SWOT analyses and SWOT strategy formulation for forest owner cooperations in Austria. Eur. J. For. Res. 126(3): 413 420. DOI: $10.1007 / \mathrm{s} 10342-006-0162-2$

Reihanian A, Mahmood NZB. Kahroom E, Hin TW. 2012. Sustainable tourism development strategy by SWOT analysis: Boujagh National Park, Iran. Tour. Manag. Perspect. 4: 223-228. DOI: 10.1016/j.tmp.2012.08.005.

Srivastava PK., Kulshreshtha K, Mohanty CS, Pushpangadan P, Singh A. 2005. Stakeholder based SWOT analysis for successful municipal solid waste in Lucknow, India. Waste Manag. 25: 531-537. DOI: 10.1016/j.wasman.2004.08.010

Statistics Indonesia. 2009. Export and Import of ornamental plants 2003-2008, foreign trade statistics. www.bps.go.id. [Indonesian]

Swarts ND, Dixon KW. 2009. Terrestrial orchid conservation in the age of extinction. Ann. Bot. 104: 543-556. DOI: 10.1093/aob/mcp025.

Tsiftis S, Tsiripidis I, Karagiannakidou V, Alifragis D. 2008. Niche analysis and conservation of the orchids of East Macedonia (NE Greece). Acta Oecologica 33: 27-35. DOI: 10.1016/j.actao.2007.08.001.

Yahman. 2009. Structure and Composition of Orchid in Hutan Wisata Taman Eden, Toba Samosir Regency, North Sumatera Province. [Master Thesis]. Universitas Sumatera Utara, Medan. [Indonesian]

Yulia ND, Budiharta S. 2011. Epiphytic orchids and host trees diversity at Gunung Manyutan Forest Reserve, Wilis Mountain, Ponorogo, East Java. Biodiversitas 12 (1): 22-27. DOI: 10.13057/BIODIV/D120105. 